\title{
PENDIDIKAN KEINDONESIAAN DALAM \\ PENGEMBANGAN PENDIDIKAN ISLAM BERBASIS \\ BUDAYA LOKAL
}

\author{
Oleh: \\ Moh. Turmudi ${ }^{*}$
}

\section{Abstraks.}

Speaking of local cultural values as a cultural product of local communities, their presence at the level of the nation state is getting lost, especially when faced with the challenges of the global community. Indonesia's national culture merely as a formal object, because the object is actually a regional culture material including educational values in the area.

That is why in the study of educational thought Indonesia needed an invention of tradition to create a building-type non western scientific education that seeks consciously undertake concrete activities continuing to improve, remodel, renew life system, social order or the state administration that reinforce values.

Cultural studies utilizing multidisciplinary studies in cultural perspective. As it is known that the culture has a universal culture of the seven sectors, namely art, system technology, religion, social organization, knowledge systems, economic systems, and languages.

Kata Kunci, Pendidikan Keindonesiaan, Pendidikan Islam berbasis Budaya Lokal.

\section{Pendahuluan}

Tahun 1596 merupakan babak baru pertumbuhan kebudayaan di Indonesia, karena kehadiran VOC (Vereenigde Oost Indische Compagnie) sebuah perseroan dagang Belanda di

\section{* IAIT Kediri}


Timur Jauh yang kelak berubah menjadi kolonialisme berabadabad lamanya. Kompeni Belanda ${ }^{5}$ banyak melibatkan diri dalam usaha-usaha keamanan daerah pantai dan selanjutnya di daerah pedalaman, terutama di Jawa.

Mozaik kebudayaan Indonesia tersebut, baik pengaruh Hindu-Buddha, Islam, dan pengaruh Barat (Eropa) yang sekaligus membawa agama Kristen, dalam perkembangannya terus berkembang dan berinteraksi dengan kebudayaan dengan keyakinan spiritual suku adat. Gelombang sejarah dan politik menjadikan berbagai kebudayaan tetap bertahan, berubah, bersinkretik, berakulturasi, sampai sekarang. Masing-masing memiliki kearifan yang melekat dan diyakini sebagai sebuah adat dan kebiasaan. Kearifan lokal, baik dalam sektor bahasa dan sistem tulisnya, sistem ekonomi, sistem pengetahuan tradisional, organisasi sosial, religi dan sistem kepercayaan maupun sistem teknologi tetap dipertahankan dan dipelihara masyarakat pendukungnya menjadi kearifan tradisional.

Perjalanan panjang sejarah kebudayaan di Indonesia menjadikan Indonesia memiliki keragaman adat istiadat dan beberapa bentuk kearifan tradisional yang menarik minat bangsa Barat terutama di kalangan ahli etnologi dan antropologi melakukan banyak penelitian. Kehadiran bangsa India di nusantara selain tersebarnya agama Hindu-Buddha, ${ }^{1}$ juga tersebarnya kebudayaan baik yang berupa bahasa dan sistem tulisan, kesenian, sistem teknologi, organisasi sosial, sistem pengetahuan dan sistem ekonomi. Selanjutnya kedatangan para pedagang dari Persia semenjanjung Arab dan Gujarat, sambil berdagang menyebarkan agama dan peradaban Islam. ${ }^{2}$ Sudah

${ }^{5}$ Belanda juga selama bertahun-tahun menjalankan pengaruh terhadap pemerintahan dan perdagangan di daerah pantai dan pedalaman. Akibatnya ketika pemerintah Belanda mengambil alih utang-piutang, VOC bangkrut. Masa inilah babak baru penjajahan pemerintah kerajaan Belanda di nusantara.

${ }^{1}$ Kebudayaan dan peradaban Hindu-Buddha berkembang pesat di Indonesia, terutama di pulau Jawa dan Sumatra yang pengaruhnya sampai 300 tahun melalui kekuasaan raja-raja nusantara yang beragama HinduBuddha.

${ }^{2}$ Penyebaran Islam dari bagian utara dan barat Indonesia di abad ke-7 Masehi, terutama puncaknya abad ke 11 dan 12. Kehadiran Islam dapat 2

Volume 26 Nomor 1 Januari 2015 
sejak lama Indonesia dikenal memiliki beragam kebudayaan yang tersebar di seluruh wilayah negara kesatuan Republik Indonesia. Keragaman Budaya yang ada bersignifikan dengan keragaman 500 suku bangsa yang kurang lebih 17.000 pulau besar dan kecil, berpenghuni dan tidak berpenghuni, ${ }^{3}$ dalam pulau yang tersebar dan kurang lebih 200 bahasa daerah, yang tersebar dari Sabang di barat sampai Merauke di timur, dari pulau Miangas di utara sampai pulau Rote di selatan. Indonesia ${ }^{2}$ telah memiliki kebudayaan dengan sistem religi dan kepercayaan yang khas animistik dan dinamistik.

Dalam perspektif keilmuan, pengaruh Barat sangat besar. Sistem Pendidikan dan persekolahan pun dikembangkan dari sistem pendidikan Barat, terutama Belanda. Filsafat ilmu pengetahuan pun mengambil konsepsi ontologis, dan epistemologis yang mendasarkan pada model Barat. Oleh karena itulah muncul corak keilmuan yang disebut western dan nonwestern. Pada umumnya pemikiran western berupaya dengan penuh kesadaran melakukan suatu kegiatan kongkret berkelanjutan untuk memperbaiki, merombak, memperbarui, tata kehidupan, tata masyarakat atau tata negara yang dirasakan tidak memuaskan.

\section{Permasalahan}

menggantikan Hinduisme dan Buddhisme yang sebelumnya telah berhasil membawa kejayaan nusantara melalui raja yang berpengaruh. Pada masa ini Islam turut menambah mozaik kebudayaan-kebudayaan di Indonesia dengan memberikan warna tradisi dan kebudayaan Islam yang akhirnya dapat diterima oleh sebagian masyarakat Indonesia.

${ }^{3}$ Budiono Kusumohamidjojo, Kebhinekaan Masyarakat di Indonesia Suatu Problematik Filsafat Kebudayaan, (Jakarta: Gramedia, 2000), h. xi

${ }^{4}$ Baik secara geopolitik, geografi, ekonomi, dan ekologis menjadikan kepulauan ini menjadi ajang pertemuan pertukaran dan percampuran kebudayaan seperti Persia, Arab, India, Asia Timur, maupun Eropa. Akibat yang tampak adalah berbagai bentuk ragam kebudayaan dan agama yang dapat tumbuh subur, baik melalui proses-proses kebudayaan seperti difusi, sinkretisme, maupun proses-proses politik seperti kolonialisme maupun sistem pemerintahan yang hegemonik maupun dominatik. Edi Sedyawati, Kebudayaan dan Pembangunan dalam Masalah Budaya dan Pariwisata dalam Pembangunan. Ed. I Gusti Ngurah Bagus. (Denpasar: S2 Kajian Budaya, 1997). 
Sejarah pemikiran pendidikan Indonesia memiliki jangkauan yang sangat luas. Pendidikan di Indonesia berkembang sejak masa pra kolonial, masa kolonial, dan masa kemerdekaan membawa implikasi kompleksnya bentuk-bentuk pendidikan di Indonesia. Pengaruh kolonialisme Barat sangat mengkondisikan pendidikan di Indonesia, terutama ketika Indonesia telah menjadi negara bangsa (Nation State) yang berbentuk Republik sehingga dalam perkembangan selanjutnya terutama dalam menghadapi perubahan sosial budaya menuju Indonesia sebagai warga dunia dalam arus masyarakat global, maka diperlukan sekali reorientasi pendidikan keindonesiaannya. Dengan menggunakan pendekatan multikulturalisme, serta menyadari keragaman nilai budaya Indonesia, maka perlu dikaji sebuah pemikiran holistik tentang pendidikan di Indonesia. Untuk itu perlu dipikirkan dan dikaji kontribusi nilai budaya lokal Kebudayaan Indonesia sebagai dasar reorientasi pendidikan keindonesiaan, khususnya dalam pengembangan ilmu pendidikan yang berbasis budaya Indonesia.

Berbicara tentang nilai budaya lokal sebagai produk kebudayaan komunitas lokal, keberadaannya dalam tataran nation state semakin hilang, apalagi bila dihadapkan pada kondisi masyarakat global. Kebudayaan nasional Indonesia hanyalah sebagai sebuah objek formal, karena objek materialnya sesungguhnya adalah kebudayaan daerah termasuk di dalamnya nilai-nilai pendidikan di daerah. Sebagai gambaran dalam bahasa, tidak sedikit pula seorang penutur bahasa Indonesia dalam praktik berbahasanya masih menggunakan sistem nilai dan pola pikir maupun rasa kedaerahan, sehingga menimbulkan perilaku berbahasa nasional yang bercorak lokal. Evoluasi sosial yang terjadi di masyarakat dalam perspektif sosiologis digambarkan merupakan pergeseran nilai dari local community menuju nation state dan global society, atau berawal dari masyarakat agaris menuju masyarakat pra industri dan masyarakat industrial.

Dalam peta politik Indonesia, bingkai budaya yang terjadi dapat dikelompokkan menjadi tiga model, yaitu budaya 
universal, ${ }^{6}$ budaya negara ${ }^{7}$ dan budaya indigenous. ${ }^{8}$ Budaya daerah dalam budaya universal kurang mendapatkan tempat karena berbagai alasan yang salah satunya politik dan ekonomi. Dalam kerangka budaya negara, nilai lokal di daerah sebagai fakta budaya yang harus diakui keberadaannya, sedangkan dalam budaya indigenous, sistem nilai merupakan ciri hidup yang teramati dan digunakan. Ketiga model budaya yang terdapat di Indonesia tersebut telah merupakan suatu gejala kebudayaan secara global.

Berdasarkan uraian tersebut jelaslah bahwa sistem pendidikan dengan model budaya indigenous atau nilai lokal merupakan suatu kenyataan yang tidak dapat dipungkiri dan keberadaannya tidak dapat dimatikan karena kehadiran sistem nasional atau sistem global yang berorientasi pada sistem Barat. Oleh sebab itulah perlu reorientasi sebagai bagian dari pencerahan nilai berpikir non western sebagaimana dikembangkannya pemikiran postkolonialisme dalam teori kebudayaan modern. Tilaar, selalu menekankan pemahaman bahwa proses pendidikan merupakan sebuah gambaran perjalanan antara hominisasi dan humanisasi. Proses hominisasi melihat manusia sebagai makhluk hidup di dalam dunia ekologisnya dan pendidikan mencapai puncaknya ketika terjadi proses humanisasi yang menjadikan seseorang akan

${ }^{6}$ Perkembangan budaya universal menjadikan dinamika budaya yang menyebabkan tercerabutnya gaya hidup dan sistem nilai lokal menuju unversalisme budaya yang meliputi seluruh aspek kebudayaan seperti sistem tulisan, penanggalan, musik, tari, sastra, perumahan, perkantoran, pengetahuan, dan lain-lain.

7 Melalui budaya negara, segala sesuatu yang berbau kedaerahan seolah-olah termarginalisasikan. Kesukuan berangsur hilang yang secara gradual berubah menjadi nation state. Prinsip kewilayahan, kewarganegaraan, sistem hukum positif prinsip kekuasaan,dan pemerintahan yang rasional muncul untuk menggantikan kesukuan dan kerajaan. Nation state yang memunculkan nasionalisme menggambarkan tentang sebuah imaji kewarganegaraan.

${ }^{8}$ Sedangkan budaya indigenous adalah budaya yang berkembang dari sistem nilai masyarakat setempat atau lokal yang seringkali didasarkan atas sistem bahasa dan hukum adat dengan indikator analisis pola-pola yang telah ada seperti pola cocok tanam, maritim, pola hukum pendidikan, maupun kesenian yang memberi format pada masyarakat pendukungnya. 
berpendidikan dan berbudaya (educated and civilized human being). ${ }^{9}$ Selanjutnya perlunya pemikiran pendidikan yang harus berorientasi budaya termasuk pada nilai lokal sebagaimana dikemukakan Vygotsky bahwa manusia akan selalu belajar di dalam konteks sosio-kulturalnya. Belajar di dalam lingkupan pengembangan zona proksimal. Dengan demikian melalui reorientasi nilai lokal dalam pemikiran pendidikan akan tercapai sebuah transformasi diri dan transformasi sosial karena nilai budaya indigenous akan memberikan nilai pendidikan yang mampu menciptakan lapisan kehidupan individu, kelompok, masyarakat dan keluarga yang beridentitas, berkontinuitas dalam tantangan perubahan masyarakat.

Memasuki milenium ketiga, wajah kehidupan manusia mulai berubah ialah suatu kebutuhan akan identitas diri. Gelombang globalisasi sebagai akibat kemajuan teknologi khususnya teknologi komunikasi dapat menyebabkan pendangkalan budaya dan kehilangan identitas. Oleh sebab itu perlu usaha untuk menghidupkan kebudayaan lokal sebagai pengangkatan jati diri dan identitas manusia dalam hidup, bertindak dan berkelakuan sehari-hari. John Naisbit pun menasihati agar manusia modern harus bisa berpikir dan bervisi global tetapi bertindak secara lokal. ${ }^{10}$

\section{Sekilas Beberapa Bentuk Pemikiran Pendidikan di Indonesia}

Nilai-nilai lokal atau nilai-nilai budaya dalam masyarakat global seperti saat ini tampaknya tidak lagi menjadi perhatian. Nilai-nilai hakiki baik yang berasal dan kearifan agama, maupun adat istiadat semakin tidak terapresiasi dalam keluarga dan masyarakat, sehingga nilai yang menjadi garis ketentuan dalarn keluarga dan masyarakat sudah berubah. Nilai-nilai lokal dalam hal etika hubungan antar individu dalam keluarga baik dalam keluarga inti maupun batih tampak semakin memudar. Terutama

9 H.A.R. Tilaar, Paradigma Baru Pendidikan Nasional. (Bandung: Rineka Cipta, 2000), h. 34

10 Wardiman Djojonegoro, Pendidikan dan Dunia Industri Mulia, Unggulan di Dalam Ilmu Pengetahuan dan Teknologi. Makalah Konvensi Pendidikan Nasional. Jakarta 19-22 September 2000. 
pada masyarakat urban. Hal yang mendasar adalah struktur pekerjaan masyarakat industri dan mobilitas sosial yang tinggi menyebabkan nilai-nilai lokal sebagai sumber keanifan tradisional dan nilai budi pekerti kita.

Sejarah sering diapresiasi kurang simpatik oleh sebagian kalangan karena sifat "telah berlalu"/"the past"-nya. Hal ini kurang bijaksana karena sebenarnya sejarah tidak akan pernah berdusta. Jangan hanya karena atas nama industrialisasi, modernisasi dan teknologi, manusia dalam kebudayaan dan sejarahnya kemudian dilupakan. Sejarah, peradaban dan kebudayaan harusnya ditempatkan dalam posisi sentral. Sifat sejarah akan merekapitulasi budaya manusia termasuk di dalamnya upaya "proses menuju peradaban" (civilization) melalui tatanan sosial yang terwujud dalam pendidikan yang memberikan sentuhan halus, manusiawi dan memperkokoh akar-akar solidaritas bangsa. Melalui pendalaman akar sejarah untuk melihat pertumbuhan pendidikan pada masyarakat kita dapat disimak adanya keragaman dalam berbagai hal seperti dalam bahasa yang digunakan, bentuk dan makna serta fungsifungsi yang melekat. Hal ini disebabkan oleh keragaman pengalaman yang dijalani komunitas-komunitas pendukung tradisi baik secara diakronis sepanjang perjalanan waktu maupun sinkronis dalam persebaran ruang.

Apabila ditelusuri beberapa peninggalan tertulis maupun lisan, gambaran adat, tradisi, dan ajaran budi pekerti sangat beragam bentuknya. Ada yang berupa sastra, naskah ajaran, perilaku yang turun temurun maupun ajaran agama. Pada tahun 1905, Van Ronkel menyusun daftar naskah-naskah berbahasa Melayu $^{11}$ dan Nusantara, 95\% naskah-naskah tersebut adalah

${ }^{11}$ Naskah-naskah ini ditulis di berbagai tempat di Indonesia, seperti Aceh, Palembang, Minangkabau, Banjarmasin, Riau, Pontianak, Gorontalo, Makasar, Bima, Ternate, Lombok, Madura, Jawa (Sunda, Jawa Tengah, Jawa Timur), Banten dan Larnpung. Seni-seni adiluhung seperti sastra, seni dekoratif, setelah pertunjukan dan lain-lain menunjukkan simbol-simbol humanitas masyarakat dan keberlang sungan nilai-nilai sosial dalam tradisi yang akarnya adalah pendidikan. Penghalus rasa yang disosialisasikan melalui kebudayaan. Tembang-tembang suluk dalam bahasa Sunda, Jawa dan Madura sarat dengan ajaran pendidikan seperti, Hikayat Nabi, Kitab Tajus Salatin, Serat Menak, Hikayat Amir Hamzah, Cerita Nabi Yusuf menak Cina, Volume 26 Nomor 1 Januari 2015 
teks tentang agama, sastra, hukum, adab dan berbagai pengetahuan, yang sekarang menjadi koleksi Perpustakaan Nasional Jakarta.

Apabila kembali kita buka lembar sejarah nusantara, khususnya sejarah pendidikan sejak zaman Hindu-Budha, masuknya Islam, Barat dan zaman sesudah kemerdekaan dapat dijumpai perkembangan sistem pendidikan yang ada. Pada masa Hindu-Budha, kaum Brahmana berperan sebagai Empu atau Guru. Menurut Dr. Th. Pigeaud, peranan asrama atau mandala (the cred-ring comunities) sangat besar pengaruhnya terhadap sosialisasi nilai-nilai pendidikan kepribadian dan budi pekerti. Ajaran kebijakan, tata tertib dan agama, sastra dan seni semua bermuara pada sistem asrama (padepokan). ${ }^{12}$

Dalam masa berkembangnya agama Islam ke nusantara, membawa perkembangan dalam bentuk dan isi pendidikan budi pekerti baik secara vertikal (hubungan dengan Tuhan) maupun horizontal (hubungan antar manusia sebagai makhluk sosial). Pengaruh ini memiliki banyak ragam karena faktor adaptasi, difusi akulturasi dan sinkretisme dengan budaya lokal yang telah tumbuh dan berkembang sebelumnya. Pendidikan dalam sejarah Islam di nusantara, khususnya di Jawa berawal dengan didirikannya sistem pendidikan Pesantren $^{13}$ dengan ajaran agama Islam, khususnya a1-Qur'an, Hadist, Fiqh (hukum) dan Tasawuf (mistik) dengan sistem "sorogan".

Wedhatama, Wulangreh, Tripama, dan Syair-syair (Melayu) merupakan gambaran peninggalan sejarah dalam bentuk seni sastra yang menunjukkan akar pendidikan budi pekerti pada masa silam yang masih memiliki relevansi dengan pendidikan moral pada masa kini.

${ }^{12}$ Kaum Brahmana sebgai sumber kecakapan dan kebajikan dan sumber ilmu. Sistem pendidikan: "guru-kulla" merupakan simbol transformasi nilai yang didasarkan atas agama untuk segenap aspek kehidupan. Di Jawa pada masa lalu untuk memberikan wawasan perilaku berdasarkan ajaran agama banyak dilakukan penerjemahan karya-karya dan bahasa Sansekerta. Pada masa tersebut pendidikan merupakan bagian dari filsafat hidup dan ajaran agama. Pendidikan disampaikan melalui model wiracarita, sastra, dan "sabda" yang meliputi pendidikan kepahlawanan sebagai simbol keberanian, kebaikan dan kejujuran.

${ }^{13}$ Sebelumnya pesantren ini telah ada dalam model Hindu-Budha 
Sosialisasi pendidikan berupa penerapan kaidah-kaidah yang disyariatkan agama serta beberapa perilaku Kiai sebagai panutan (dan Lisan ke Tindakan). Selanjutnya dikembangkan sistem sekolah (Madrasah) yang mendidik keselarasan otak (perkembangan akal), hati (perkembangan perasaan dan kemanusiaan serta, tangan (perkembangan kecekatan dan keterampilan). Pendidikan budi pekerti menurut pendidikan Islam diawali dengan konsep (1) Pengajian A1-Qur'an, (2) Pengajian kitab yang menelaah Nahu, Sharaf Fiqhi, Tauhid, Mantiq, Balaghah, Hadist, dan Tafsi.

Budi pekerti sebagai pelajaran dimasukkan dalam matapelajaran Akhlak. Dalam perkembangan selanjutnya, pendidikan budi pekerti dalam bingkai pendidikan Islam dirancang berjenjang menurut usia dan kelas para siswa. Inti pendidikan budi pekerti ini bersumber pada Keimanan dan Akhlak serta Ibadat. Pada tataran keimanan dan akhlak, pendidikan diarahkan kepada penumbuhan perasaan keimanan dan keagamaan dalam hati anak-anak dengan cara memberikan cerita-cerita pendek tentang orang-orang saleh yang taat kepada agama, orang yang berani mempertahankan kebenaran, berbakti kepada ibu-bapak, seia-sekata dengan saudaranya, saling menyayangi antar teman dan sahabat serta berbuat baik untuk umum (masyarakat). Pada jenjang kelas yang lebih tinggi ajaran ibadat dipadukan dengan a1-Qur'an.

Masih dalam konteks sejarah Islam, pendidikan budi pekerti yang didasarkan agama Islam kadang-kadang mendapat pengaruh dan budaya lokal, terutama di Jawa. Seperti pada penyebarluasan Sastra Tembang ${ }^{14}$ yang dikaitkan dengan adab sopan santun dan kepribadian sebagai orang Jawa. ${ }^{15}$

14 Pada umumnya pujangga Jawa dan Raja Jawa berguru kepada seorang Kiai atau Guru Agama di Pesantren.

${ }^{15}$ Sebagai contoh Serat Wedhatama karya KGPPA Mangkoenegoro IV, Panitisastra (Yasadipura), Kalatidha (R. Ng. Ranggawarsita) dan Wulangreh karya S.D.I.S. Sunan Pakoeboewono IV, semuanya berisi ajaran cara seharusnya bergaul, mengolah jiwa, mengolah kepnibadian menuju kebajikan sebagai manusia dan anggota masyanakat (negana). Intinya adalah pendidikan.

Volume 26 Nomor 1 Januari 2015 
Kehadiran Barat (kolonialisme) juga memberikan pengaruh terhadap penanaman nilai-nilai barat yang rasional, liberal dan paham materialistik. Sistem pendidikan yang dikembangkan menekankan pada akal, rasional sehingga lebih menonjol pada aspek pengetahuan sekuler. Agama Nasrani berkembang di nusantara karena dibawa oleh bangsa Eropa, yang bermula bermisi dagang dan agama kemudian berubah menjadi politik dan kolonialisme. ${ }^{16}$

Dalam kerangka sejarah pendidikan di Indonesia sejak awal abad ke-20, nama-nama besar perintis pendidikan yang di dalamnya menyajikan sistem pendidikan keindonesiaan antara lain K.H. Ahmad Dahlan dengan Pendidikan Muhammadiyah (1912), Ki Hadjar Dewantara dengan Taman Siswa (1922), Mohammad Syafei dengan INS Kayutanam Sumatera Barat (1922), dan K.H. Hasyim Asy'ari dengan Pendidikan Ma'arif (1926).

Pendidikan dikembangkan melalui kurikulum bidang studi baik dalam pendidikan umum, pendidikan agama, dan lembaga

${ }^{16}$ Sebagai bahan ilustrasi kehadiran bangsa Eropa dengan budaya Barat yang memperkenalkan pendidikan etika dan cara berpikir Barat, khususnya dasar ajaran agama Nasrani bermula pada abad ke-19 di luar Jawa, pendidikan yang dirintis oleh kalangan Zending dan Misi. Sekolah Rakyat yang didirikan di Maluku pada tahun 1817 dan tahun 1819, Minahasa tahun 1829, Kalimantan bagian tenggara tahun 1836 dan Larantuka tahun 1876. Sedangkan d Jawa pada awal abad ke-20. Pendidikan Barat terutama Belanda inilah yang sejak abad ke-18 sampai pertengahan abad ke-20 melahirkan bentuk kebudayaan yaitu Kebudayaan Indis yang sudah tentu memiliki karakter nilai, norma dan perilaku akulturatif antara Barat (Belanda) dengan Bumi Putera. Pendidikan keruhaniian dapat dikatakan tidak ada karena agama dan budipekerti tidak tercantum dalarn kurikulum sekolah Belanda. Selain itu pada masa kolonial merebak sikap ketidakadilan dan pelanggaran hak-hak asasi manusia yang dilakukan Belanda. Justru dalam kondisi seperti ini di masyarakat tumbuh proses pembentukan kebu dayaan yang khas, yaitu kebudayaan dan gaya hidup indis (lndische stijl). Ketidak setujuan dan kekhawatiran hilangnya local genius (kepribadian asli bangsa) terhadap sosialisasi dan akulturasi ini banyak bermunculan terutama dan kaum agama dan adat. Dalam sejarah sastra Indonesia modern kita tentu mengingat karya Abdoel Moeis yang berjudul Salah Asuhan. Pada umumnya sastra Indonesia awal abad ke 20 banyak berkisah tentang pertentangan adat dan kaum "modern" yang identik dengan kaum penjajah Belanda. Baca Hildred Geertz, Aneka Budaya dan Komunitas di Indonesia. (Jakarta:Obor. 1981) 
sekolah. Ciri khas pendidikan budi pekerti diimplementasikan dalam matapelajaran Tauhid, A1-Qur'an, Hadist, Fiqh, dan Tarikh. Bentuk nyata pendidikan budi pekerti dengan; (1) mengadakan da'wah Islam, (2) memajukan pendidikan dan pengajaran, (3) menghidupsuburkan masyarakat gemar tolong menolong, (4) mendirikan dan memelihara tempat ibadah dan wakaf, (5) mendidik dan mengasuh anak-anak dan pemuda supaya menjadi muslim yang berguna, (6) berusaha ke arah perbaikan penghidupan dan kehidupan yang sesuai dengan ajaran Islam, dan (7) berusaha dengan segala kearifan agar ajaran akhlak dalam Islam benar-benar menjadi panutan masyarakat.

Selanjutnya pendidikan bernuansa nasional adalah Taman Siswa (1922) yang didirikan oleh R.M. Soewardi Soerjaningrat atau Ki Hadjar Dewantara (1889-1959). Taman Siswa atau National Onderwijs Institute Tarnan Siswa yang mengembangkan pendidikan berdasarkan sistem among. Dua dasar sistem among yang dikembangkan Taman Siswa, yaitu (1) kemerdekaan sebagai syarat untuk menghidupkan dan menggerakkan kekuatan lahir dan batin, sehingga jiwa dapat hidup merdeka (berdiri sendiri), (2) kodrat alam sebagai syarat untuk menghidupkan dan mencapai kemajuan secepat-cepatnya dan sebaik-baiknya.

Asas yang dikembangkan Taman Siswa adalah asas kemerdekaan, kodrat alam, kebudayaan, kebangsaan, dan kemanusiaan. Budi pekerti dalam pendidikan dikembangkan berdasarkan nilai-nilai (1) lawan sastra ngesti mulya atau kecerdasan jiwa memberikan kesejahteraan, (2) suci tata ngesti tunggal atau kesucian batin dan keteraturan hidup dalam niemberikan kesempurnaan, (3) tut wuri handayani yang artinya mengikuti dan belakang sambil memberikan pengaruh, (4) anak sebagai subjek didik sehingga harus selalu dikasihi, dan (5) rawe-rawe rantas, malang malang putung, bahwa segala sesuatu yang menghalangi pasti akan hancur.

Dalam waktu yang hampir bersamaan di Sumatera Barat didirikan pendidikan INS (dulu "Indonesische Nederlandsche School," kini "Indonesia National School") oleh tokoh pendidikan Mohanimad Syafei (1899-1969). Pendidikan 
dikembangkan berdasarkan nilai kemasyarakatan, aktivitas, kepraktisan, berpikir logis dan rasional. Oleh karena itu, sistem pendidikan INS yang terkenal adalah $3 \mathrm{H}$ (Head, Heart, dan Hand). Model pendidikan yang lahir di Sumatera Barat ini bertujuan agar siswa mampu berpikir secara rasional, mendidik anak-anak agar mampu bekerja dengan teratur dan sungguhsungguh, mendidik, anak agar menjadi manusia yang berwatak dan berbudi pekerti yang baik, serta menanamkan rasa persatuan. Pada 1926, K.H. Hasyim Asy'ari (1871-1947) mendirikan Nahdlatul Ulama (NU) yang juga memperhatikan masalah pendidikan. Pendidikan di kalangan NU lebih dikenal dengan Pendidikan Ma'arif. Tujuan pendidikan Ma'arif adalah: (1) menumbuhkan jiwa pemikiran dan gagasan yang dapat membentuk pandangan hidup bagi anak didik sesuai dengan ajaran Ahlussunah waljama'ah, (2) menanamkan sikap terbuka, watak mandiri, kemampuan bekerjasama dengan pihak lain untuk lebih baik, keterampilan menggunakan ilmu pengetahuan dan teknologi, (3) menciptakan sikap hidup yang beronientasi kepada kehidupan duniawi dan ukhrawi sebagai sebuah kesatuan, dan (4) menanamkan penghayatan terhadap nilai-nilai ajaran agama Islam sebagai ajaran yang dinamis.

Dengan demikian pendidikan yang ditanamkan berdasarkan ajaran Ahlussunah waljama'ah dan nilai-nilai ajaran agama Islam secara dinamis. Setelah masa kemerdekaan, pendidikan budi pekerti diorientasikan kepada pembentukan jiwa pribadi anak didik sebagai individu yang hidup di tengahtengah pergaulan masyarakat khususnya dalam hidup bernegara. Hal ini mengalami pasang surut sebagai akibat dinamika pertumbuhan politik dan masa itu. Krisis ini muncul sosialisme, komunisme, atheisme mulai dipraktikkan oleh sekelompok/segolongan masyarakat yang memuncak tahun 1965. Trauma yang dialami bangsa Indonesia pasca G3OS/PKI melahirkan semangat untuk kembali kepada jatidiri bangsa yang berdasarkan agama dengan menjunjung tinggi nilai-nilai kemasyarakatan, sehingga pada era orde baru Agama dan Pancasila dijadikan pedoman pendidikan budi pekerti baik di lingkungan keluarga, sekolah, maupun masyarakat. Pada masa orde baru pembinaan tolok ukur yang dikembangkan di 
lingkungan pendidikan menggunakan sumber pendidikan Agama dan pendidikan Pancasila yang saling mendukung. Tentunya hal ini memiliki konsekuensi positif maupun negatif.

Di satu sisi memberikan struktur yang baik, di sisi lain local genius tidak mesti harus diseragamkan. Perbedaan tetap harus dipandang dengan eksistensi yang diwarisi dan kearifan adat dam tradisionalnya. Selama orde baru nilai-nilai moral yang merupakan inti kebudayaan (kearifan tradisional) telah diredusiasi menjadi nilai-nilai indoktrinasi kekuasaan tanpa arti dan sekadar semboyan dalam bentuk simbol-simbol "sentralisme pendidikan dan kebudayaan."

\section{Invention of Tradition sebagai Reorientasi Pendidikan Makna Nilai Lokal melalui Pendekatan Kajian Budaya}

Masa depan adalah suatu waktu yang ditengarai dengan adanya perubahan sebagai hasil evolusi pendidikan, teknologi, kompetitif, pengetahuan, demografis dan evolusi dalam kebangkitan hal-hal di luar dugaan. Oleh sebab itulah dalam kajian pemikiran pendidikan Indonesia diperlukan suatu invention of tradition $^{17}$ untuk mewujudkan sebuah bangunan keilmuan pendidikan bertipe non western yang berupaya dengan penuh kesadaran melakukan kegiatan kongkret berkelanjutan untuk memperbaiki, merombak, memperbarui tata kehidupan, tata masyarakat atau tata negara yang meneguhkan nilai.

Kajian budaya memanfaatkan multidisiplin dalam kajiankajian perspektif kebudayaan. Sebagaimana diketahui bersama bahwa kebudayaan memiliki tujuh sektor kebudayaan universal, yaitu kesenian, sistem teknologi, religi, organisasi sosial, sistem pengetahuan, sistem ekonomi, dan bahasa. Perkembangan suatu masyarakat terutama pada masyarakat multikultural sangat kompleks, untuk itu perlu didekati dalam berbagai disiplin dalam perspektif kebudayaan. Kompleksitas masyarakat majemuk berkembang menjadi sangat beragam dari segi ras, etnisitas, maupun latar belakang budaya. Kajian budaya mengimbangi suatu kebijakan multikultural (aneka-budaya)

17 Tradisi yang ditemukan, dikonstruksi, dan secara formal diadakan reinterpretasi dan reorientasi

Volume 26 Nomor 1 Januari 2015 
sehingga dapat menjadi sebuah pendekatan. Fenomena dualistik masyarakat yang menyebabkan adanya superioritas dan marginalitas, ada yang sektor ada yang terpinggirkan, ada hegemoni dan dominasi, merupakan fakta-fakta yang dapat dikaji secara multi disiplin dan apabila berperspektif multi kultur akan dikaji dalam kajian budaya.

Kajian Budaya atau Cultural Studies bertujuan mengkaji pokok persoalannya dari sudut praktik kebudayaan dan hubungannya dengan kekuasaan. Secara tetap Kajian Budaya atau Cultural Studies bertujuan mengungkapkan hubungan kekuasaan dan mengkaji bagaimana hubungan tersebut mempengaruhi dan membentuk praktik kebudayaan. Selanjutnya dinyatakan bahwa beberapa karakteristik Kajian Budaya atau Cultural Studies adalah (a) Kajian Budaya atau Cultural Studies tidak hanya studi tentang budaya, seakan-akan merupakan entitas tersendiri yang terpisah dari konteks sosial dan politiknya. Tujuannya adalah memahami budaya dalam segala bentuk kompleksnya serta menganalisis konteks sosialdan politik tempat budaya mengejawantahkan dirinya, (b) budaya dalam Kajian Budaya atau Cultural Studies selalu menampilkan dua fungsi yaitu sebagai objek studi maupun lokasi tindakan dan kritisisme politik, sehingga merupakan bidang pragmatis maupun intelektual, (c) Kajian Budaya atau Cultural Studies berupaya membongkar dan mendamaikan pengotakan pengetahuan, mengatasi perpecahan antara bentuk pengetahuan yang tidak tersirat yaitu pengetahuan intuitif berdasarkan budaya lokal dan objek yang berupa budaya universal. Dalam kaitannya dengan hal ini Kajian Budaya atau Cultural Studies mengasumsikan suatu identitas bersama dan kepentingan bersama antara yang mengetahui dan diketahui, antara pengamat dan yang diamati, dan (d) Kajian Budaya atau Cultural Studies melibatkan dirinya dengan evaluasi moral masyarakat modern dan dengan garis radikal tindakan politik. Tradisi Kajian Budaya atau Cultural Studies bukanlah tradisi kesarjanaan yang bebas nilai, melainkan tradisi yang 
mempunyai komitmen bagi rekonstruksi sosial dengan melibatkan diri dalam kritik politik. ${ }^{18}$

Dengan demikian Kajian Budaya atau Cultural Studies bertujuan memahami dan mengubah struktur dominasi, khususnya pada masyarakat kapitalis industrial. Sehubungan dengan pernyataan kajian budaya bukanlah tradisi kesarjanaan yang bebas nilai dilandasi dasar konsepsi bahwa nilai itu sesungguhnya adalah kebudayaan. Kebudayaan merupakan cara hidup yang dihayati dan diolah melalui perkembangan komulatifdari pengalaman sejarah bangsa dan bila kebudayaan harus dikaitkan pada kehidupan dan pertumbuhan sesuatu bangsa, maka ilmu pengetahuan dan teknologi harus merupakan bagian yang integral dari kebudayaan bangsa yang bersangkutan. ${ }^{19}$

Berdasarkan beberapa pernyataan di atas, konsepsi dan karakteristik Kajian Budaya atau Cultural Studies apabila dikaitkan dengan filsafat ilmu akan tampak sangat jelas beberapa kaitannya, baik dalam aspek ontologi, epistemologi, maupun aksiologinya. Ontologis kajian budaya tampak pada hakikat ilmu ini sebagai bentuk inter-disiplin dan multi-disiplin. Sebagai inter-disiplin, kajian budaya merupakan bentuk yang khas dalam tataran ilmu. Tidak terlalu mengherankan apabila kajian budaya tidak memiliki suatu wilayah subjek yang didefinisikan secara jelas. ${ }^{20}$ Titik pijaknya adalah sebuah gagasan tentang budaya yang sangat luas dan mencakup segala hal yang digunakan untuk menggambarkan dan mempelajari beraneka praktik. Kajian Budaya mengambil apapun yang dibutuhkan dari semua disiplin dan mengadopsinya untuk disesuaikan dengan tujuannya. Sebagai inter dan multi-disiplin, kajian budaya akan melibatkan disiplin keilmuan seperti sosiologi, antropologi, psikologi, linguistik, kritisisme sastra, teori seni, filsafat, ilmu politik. Sisi ontologis (asumsi filosofis

${ }^{18}$ Zianuddin Sardar dan Borin Van Loon. Mengenal Cultural Studies for Beginners. (Bandung: Mizan, 2001), h. 9.

${ }_{19}$ Ahmad Sahal, Cultural Studies, Politik Identitas dan Esensialisme Strategis. Makalah Seminar Nasional Kajian Budaya dan Sastra Fak.Sastra UK Petra Surabaya 23 Nopember 2000.

${ }^{20}$ Sardar, Mengenal Cultural, h. 6. 
tentang kebenaran dan kenyataan) kajian budaya apabila dikaitkan dengan pandangan Aristotels, khususnya dalam konsep segala sesuatu yang ada yang terdiri dari empat kausa, yaitu materialis, formalis, finalis, dan esesialisme, maka kajian budaya telah memiliki keempat kausa tersebut. Dari aspek materialis jelas, bahwa bahan kajian budaya memanfaatkan secara bebas dari sisiplin ilmu sosial, seluruh cabang humaniora dan seni. Kausa formalisnya jelas, bahwa pendiri kajian budaya atau cultural studies atau kajian budaya. ${ }^{21}$ Nama cultural studies berasal dari Centre for Contemporary Cultural Studies (CCCS) di Univesitas Birmingham Inggris, pada 1962. Tahun 1972 lembaga ini meletakkan kajian budaya pada peta intelektual. Kausa finalis kajian budaya, sebagaimana dikemukakan oleh Simon During dalam The Cultural Studies Reader 1993 bahwa melalui kajian budaya dapat diketahui genealogisnya bahwa kebudayaan sebagai efek hegemoni dan dominasi. ${ }^{22}$ Selain itu menurut Raymond Williams melihat bahwa kebudayaan sebagai ekspresi spesifik komunitas organik yang koheren dan melawan determinisme dalam berbagai bentuknya. Sedangkan dalam kausa efisien, tampak dengan jelas dalam fokus yang dikembangkan kajian budaya yaitu bagaimana budaya dipraktikkan dan bagaimana budaya diciptakan atau bagaimana budaya memungkinkan berbagai kelompok dan kelas berjuang demi dominasi kebudayaan. ${ }^{23}$

Dilihat dari epistemologinya, kajian budaya menggunakan hampir setiap metode dari analisis tekstual, etnografi, dan psikoanalisis serta riset survei. Sebagaimana telah dinyatakan di atas bahwa kajian budaya berfungsi dengan meminjam secara bebas dari disiplin ilmu sosial dan seluruh cabang humaniora dan seni serta mengambil metodologi dari sosiologi, antropologi, psikologi, linguistik, kritik sastra, teori seni, filsafat maupun ilmu politik dan diadopsi untuk disesuaikan dengan

${ }^{21}$ Ibid., h. 24.

${ }^{22}$ Ahmad Sahal, Cultural Studies, Politik Identitas dan Esensialisme Strategis. Makalah Seminar Nasional Kajian Budaya dan Sastra Fak.Sastra UK Petra Surabaya 23 Nopember 2000.

${ }^{23}$ Suwarsih Warman, Stereotip Etnis dalam Masyarakat Multi Etnis. (Yogyakarta: Matabangsa. 2002), h. 67. 
tujuan kajian. Dengan kata lain meskipun kajian budaya tidak memiliki metodologi khusus, kajian budaya dapat memakai metode apa saja yang ada, seperti analisis tekstual, semiotika, dekonstruksi, etnografi, wawancara, analsisis fonemik, psikoanalisis, rhizomatik, analisis isi, riset survey, semua dapat dipakai sesuai konteks dan masalahnya. Sedangkan aspek aksiologis kajian budaya sebagaimana nilai tanggung jawab sosial serta sifat epistemologisnya yang cenderung pilihan praktis, pragmatis, strategis dan refletif, melalui kajian budaya dapat melihat secara pragmatik seluruh ragam budaya yang terjadi di masyarakat multikultural.

Keterkaitan kajian budaya sebagai alat kajian invention of tradition dalam pendidikan yang berbasis budaya indegenous jelas, meskipun tidak ada pendidikan yang langsung berkaitan dengan kajian budaya dibandingkan dengan misalnya sosiologi pendidikan atau antropologi pendidikan tampak bahwa hal ini dapat dijadikan sebagai pijakan rasional dan meningkatkan moral keilmuan seiring dan berkaitan dengan peningkatan kemampuan penalaran ilmiah. Sebagaimana legasi intelektual kajian budaya yang menyebutkan (a) kajian budaya merupakan tradisi intelektual dan politik kebudayaan yang dapat digunakan untuk landasan sebuah analisis kritis, objek studi, dan wilayah intervensi dan kritik, (b) kajian budaya tumbuh dari usaha untuk memahami proses pembentukan masyarakat modern, masyarakat pada negara-negara pasca perang, dan wilayah kebudayaan industri, modernisasi, urbanisasi, komunikasi massa maupun disintegrasi.

\section{Kesimpulan}

Nilai budaya lokal untuk reorientasi pendidikan keindonesia-an dalam rangka pengembangan ilmu pendidikan yang berbasis budaya Indonesia dirasa perlu untuk benar-benar mewujudkan cita-cita pendidikan Indonesia yaitu masyarakat yang demokratis, cerdas secara intelektual, emosional, etika dan estetika sehingga benar-benar educated and civilized human being. Kebhinbekaan budaya nusantara menuntut eksistensi salah satunya dalam wujud penggalian nilai--nilai budaya lokal untuk pendidikan yang khas yaitu pendidikan keindonesiaan. 
Dengan mengupayakan reorientasi nilai budaya lokal dalam pengembangan ilmu pendidikan yang berbasis budaya Indonesia ini tersirat komitmen dan pemeliharaan budaya lokal untuk menyumbang budaya nasional khususnya sumbangan unsur-unsur budaya lokal. Tujuan akhirnya adalah membangun sebuah sistem berpikir dalam khazanah keilmuan melalui rancangan sebuah filsafat pendidikan khas Indonesia. Banyaknya suku bangsa di Indonesia (250 kelompok sub etnis) memungkinkan pendekatan multikulturalisme dalam bingkai kajian budaya sebagai alat analisis sosial kritis untuk sebuah pendidikan keindonesiaan mengingat Indonesia merupakan sebuah realitas antropologis-historis. 
Pendidikan Keindonesian... Oleh: Moh. Turmudi

\section{Daftar Pustaka}

Djojonegoro, Wardiman. Pendidikan dan Dunia Industri Mulia, Unggulan di Dalam Ilmu Pengetahuan dan Teknologi. Makalah Konvensi Pendidikan Nasional. Jakarta: 19-22 September 2000.

Geertz, Hildred. Aneka Budaya dan Komunitas di Indonesia. Jakarta: Obor, 1981.

Kusumohamidjojo, Budiono, Kebhinekaan Masyarakat di Indonesia Suatu Problematik Filsafat Kebudayaan. Jakarta: Gramedia, 2001.

Sahal, Ahmad, Cultural Studies, Politik Identitas dan Esensialisme Strategis. Makalah Seminar Nasional Kajian Budaya dan Sastra Fak.Sastra UK Petra Surabaya 23 Nopember 2000.

Sardar, Zianuddin dan Borin Van Loon, Mengenal Cultural Studies for Beginners, Bandung: Mizan, 2001.

Sedyawati, Edi. Kebudayaan dan Pembangunan dalam Masalah Budaya dan Pariwisata dalam Pembangunan. Ed. I Gusti Ngurah Bagus. Denpasar: S2 Kajian Budaya, 1997.

Tilaar, H.A.R. Paradigma Baru Pendidikan Nasional, Bandung: Rineka Cipta, 2000.

Warman, Suwarsih, Stereotip Etnis dalam Masyarakat Multi Etnis. Yogyakarta: Matabangsa, 2002. 